\title{
Evaluation of Performance of Thermal and Electrical Hybrid Adsorption Chiller Cycles with Mechanical Booster Pumps
}

\author{
Tao Zeng ${ }^{1}$, Takehiro Esaki1 ${ }^{*}$, Jun Li ${ }^{1}$, Noriyuki Kobayashi' ${ }^{1}$, Hongyu Huang2 \\ ${ }^{1}$ Department of Chemical Engineering, Nagoya University, Nagoya, Japan \\ ${ }^{2}$ Integrated Technology Center, Guangzhou Institute of Energy Conversion, Chinese Academy of Sciences, Guangzhou, China \\ Email: *esaki@energy.gr.jp
}

How to cite this paper: Zeng, T., Esaki, T., Li, J., Kobayashi, N. and Huang, H.Y. (2017) Evaluation of Performance of Thermal and Electrical Hybrid Adsorption Chiller Cycles with Mechanical Booster Pumps. Journal of Materials Science and Chemical Engineering, 5, 22-32.

https://doi.org/10.4236/msce.2017.55003

Received: February 21, 2017

Accepted: May 24, 2017

Published: May 27, 2017

Copyright $\odot 2017$ by authors and Scientific Research Publishing Inc. This work is licensed under the Creative Commons Attribution International License (CC BY 4.0).

http://creativecommons.org/licenses/by/4.0/

(c) (i) Open Access

\begin{abstract}
Large amounts of waste heat below $100^{\circ} \mathrm{C}$ from the industrial sector are released into the atmosphere. It has been suggested that energy system efficiency can be increased with adsorption chillers. However, the cooling power and coefficient of performance (COP) of conventional adsorption chillers significantly decrease with the desorption temperature. In this paper, we proposed a mechanical booster pump (MBP)-assisted adsorption chiller cycle, and evaluated its performances. In the cycle, a MBP was incorporated into a zeolite-water-type adsorption chiller for facilitating water vapor transportation between an adsorber and an evaporator/condenser. We have experimentally studied the effect of the input electrical power of MBP on the performances of adsorption chiller cycle. It has been demonstrated that the heat input achieved by using $\mathrm{MBP}$ at the desorption temperature of $50^{\circ} \mathrm{C}$ was 1.6 times higher than that of without $\mathrm{MBP}$ at the desorption temperature of $60^{\circ} \mathrm{C}$. And the increase of pump power was found to be effective in increasing the heat input. Therefore, it was confirmed that the operation range of desorption temperature, which can be generated by using the waste heat, was extended and the cooling power was increased directly by using MBP.
\end{abstract}

\section{Keywords}

Adsorption, Chiller Cycle, Zeolite/Water Pair, Mechanical Booster Pump

\section{Introduction}

Since the Industrial Revolution, energy consumption has increased. This has led to an increase in the amount of industrial waste heat as well. Cogeneration systems have attracted increasing attention over the past two decades due to the 
high energy efficiency (e.g. $80 \%$ when a gas turbine with waste heat boiler is used). The energy efficiency of cogeneration system can also be improved with the use of a heat energy conversion apparatus. Adsorption chiller, as one of the heat energy conversion apparatus, can use low-temperature heat source of $60^{\circ} \mathrm{C}$ - $100^{\circ} \mathrm{C}$ to generate the desired cooling effect for reducing air-conditioning loads. The refrigeration cycle generates the cooling effect by means of adsorption, absorption, and chemical reaction phenomena [1] [2] [3]. In particular, the adsorption chiller cycle has recently been receiving a lot of attention. The adsorption chiller cycle can be used to store waste heat and supply cold energy at low temperatures. Water-zeolite [4], Water-silica gel and Ammonia-activated carbon pairs [5] are some of the most common refrigerant-adsorbent pairs used in adsorption chillers. An adsorption chiller cycle using $\mathrm{H}_{2} \mathrm{O}$ or $\mathrm{NH}_{3}$ refrigerant is considered to be an environment-friendly product. In a previous study, Kakiuchi et al. [6] introduced a new Functional Adsorbent Material-Zeolite 01 (FAM-Z01), which is an AFI-type structure Ferroaluminophoshate Zeolite (FAPO-5) with iron content of $2-8 \mathrm{~mol} \%$ [6]. It was suggested that the adsorption capacity of FAM-Z01 was four times than that of silica gel at a desorption temperature of $60^{\circ} \mathrm{C}$. However, the adsorption chiller cycle still has a few problems in practical use; by reason of the cooling power per unit volume of the adsorber and the COP are smaller than that of absorption chiller or vapor compression chiller.

To solve the problems associated with the adsorption chiller cycle, we proposed a hybrid adsorption chiller which contained a mechanical booster pump (MBP) in the adsorption step or desorption step. Figure 1 shows the schematic diagram of the hybrid adsorption chiller cycle. It consists of an evaporator, a condenser, a MBP and an adsorber. All the units are connected under reduced pressure. The MBP is set either between the evaporator and the adsorber or between the adsorber and the condenser. The adsorption core which is installed in the adsorber consists of a heat exchanger filled with adsorbents. The heat associated with the adsorption or desorption phenomenon is removed or supplied by heat exchanger. The adsorption chiller cycle consists of an adsorption step and a desorption step. In the adsorption step, the refrigerant vapor moves from the evaporator to the adsorber, and then be adsorbed. In the desorption step, the desorption heat is supplied to the adsorber, and the desorbed refrigerant vapor moves to the condenser. In the hybrid cycle, MBP, which runs on electricity, pumps the refrigerant vapor from the evaporator to the adsorber to increase the adsorber pressure of vapor in adsorption cycle or pumps the refrigerant vapor from the adsorber to the condenser to decrease the adsorber pressure of vapor in desorption cycle. The change of pressure improves the adsorbent capacity.

Figure 2 shows the adsorption isotherms of water on FAM-Z05. From Figure 2 (1), it can be seen that FAM-Z05 can generate $15^{\circ} \mathrm{C}$ cold heat at the desorption temperature of $55^{\circ} \mathrm{C}$. However, it cannot generate $10^{\circ} \mathrm{C}$ cold heat when it desorbs at $50^{\circ} \mathrm{C}$ or less (2). On the other hand, in the hybrid adsorption cycle, for example when the evaporator temperature is $10^{\circ} \mathrm{C}$, the refrigerant vapor from 


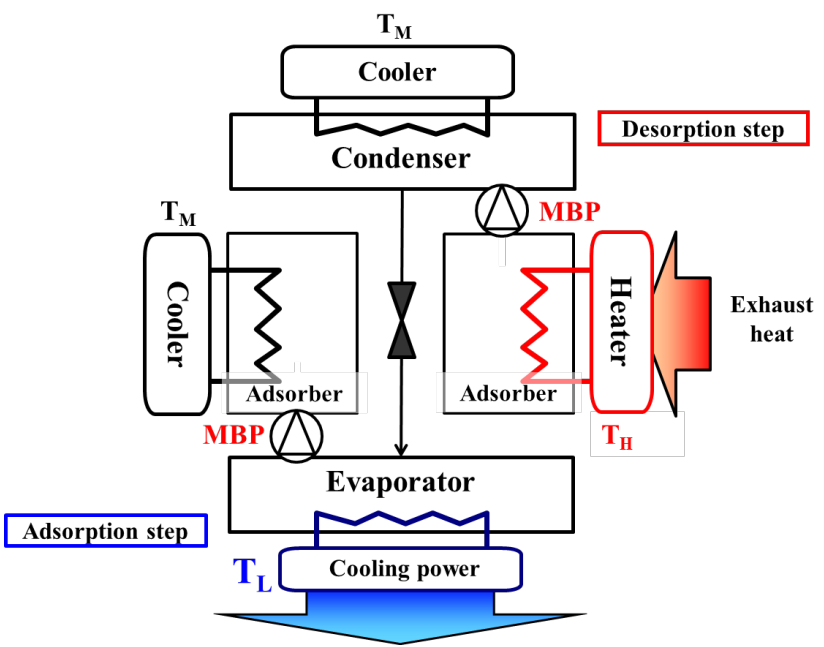

Figure 1. Schematic diagram of hybrid adsorption chiller cycle with MBP.

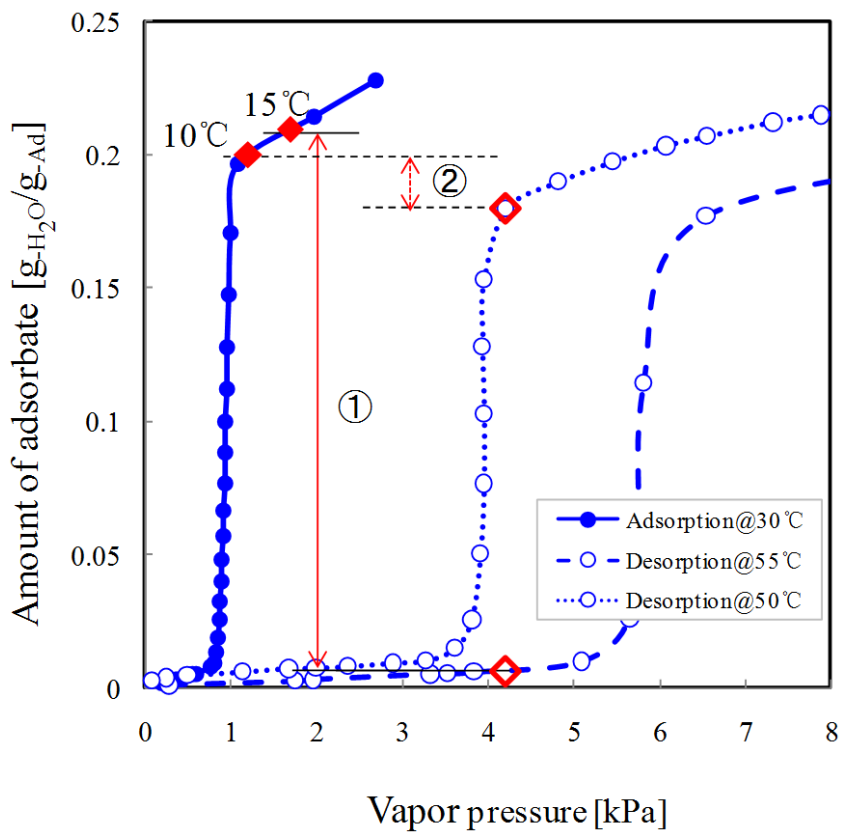

Figure 2. Adsorption isotherms of water on FAM-Z05.

the evaporator at the saturation pressure of $1.2 \mathrm{kPa}$ can be compressed by the MBP, when the adsorber pressure rises to $1.7 \mathrm{kPa}$, the amount of adsorption is increased and has the same value as the condition that the evaporator temperature is $15^{\circ} \mathrm{C}$ without MBP. In the hybrid desorption cycle, desorption can take place when the vapor pressure of the adsorber is depressurized to $1 \mathrm{kPa}$ at $50^{\circ} \mathrm{C}$ by MBP. The amount of desorption is equal to that of desorption under the condition of desorption temperature is $55^{\circ} \mathrm{C}$ without MBP. In this way, we can use MBP to expand the amount of adsorption or desorption by increasing or decreasing the vapor pressure of the adsorber. Therefore, the hybrid chiller cycle can be used at a large range of operation temperatures.

In this study, we investigated the laboratory scale hybrid chiller cycle which consists mainly of a MBP and an adsorber with the FAM-Z05 adsorption core. 
We evaluated the cooling output and desorption heat input of the hybrid chiller cycle, and researched the effect of the input electrical power of the MBP on the performances of hybrid cycle.

\section{Experimental Procedure}

Figure 3 shows the schematic diagram of the experimental apparatus. Falling liquid film heat exchangers were used in the evaporator and the condenser, which had high heat transfer performance. Figure 4 shows the adsorption cores in the adsorber. Three pairs of adsorption cores were connected in series in the adsorber, and each pair was composed of two flat webbed tube and corrugated fin heat exchangers in parallel and FAM-Z05, had an average particle diameter of $5 \mu \mathrm{m}$, was coated around the tubes and fins of heat exchangers by epoxy binder. The coating thickness of adsorbent was $100 \mu \mathrm{m}$. MBP (MBS-052 type, ULVAC Inc.) was connected with stainless tubes and the rotating speed was

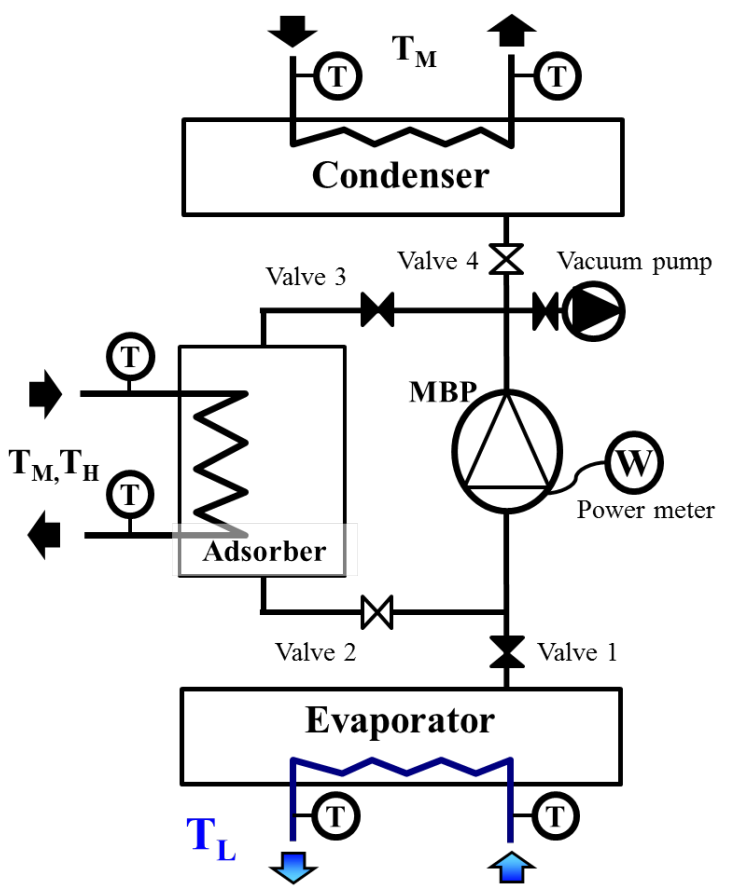

Figure 3. Schematic diagram of the experimental apparatus.

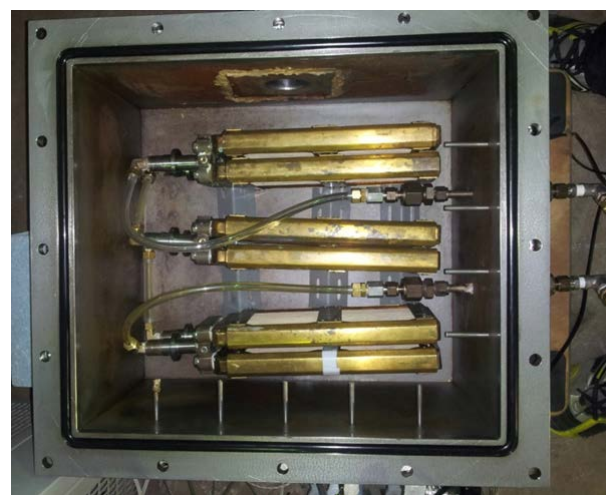

Figure 4. Photo of adsorption cores in the adsorber. 
Table 1. Experimental conditions.

\begin{tabular}{ccc}
\hline Step & Adsorption Step & Desorption Step \\
\hline Evaporator & $10^{\circ} \mathrm{C}, 15^{\circ} \mathrm{C}$ & $15^{\circ} \mathrm{C}$ \\
Adsorption temperature & $30^{\circ} \mathrm{C}$ & $30^{\circ} \mathrm{C}$ \\
Desorption temperature & $60^{\circ} \mathrm{C}$ & $60^{\circ} \mathrm{C}, 55^{\circ} \mathrm{C}, 50^{\circ} \mathrm{C}, 45^{\circ} \mathrm{C}$ \\
Condenser & $30^{\circ} \mathrm{C}$ & $30^{\circ} \mathrm{C}$ \\
MBP power & $20,60,100 \mathrm{~W}$ & $50,60,100 \mathrm{~W}$ \\
\hline
\end{tabular}

controlled by Lab View (National Instrument Inc.). When MBP was driven, we measured the electrical power consumption of it.

The experimental conditions are summarized in Table 1. The condenser temperature was maintained at $30^{\circ} \mathrm{C}$ by thermostat bath. The evaporator temperature was set at $10^{\circ} \mathrm{C}$ and $15^{\circ} \mathrm{C}$. The desorption temperature was set at $45^{\circ} \mathrm{C}$, $50^{\circ} \mathrm{C}, 55^{\circ} \mathrm{C}$ and $60^{\circ} \mathrm{C}$. The flow rate of the heat transfer fluid of all the units was set at a constant value of $4.5 \mathrm{~L} / \mathrm{min}$. The temperature of the fluid flow was measured by a Platinum resistance temperature sensor. This was followed by the calculation of cooling heat output, desorption heat input, amount of cooling heat and desorption heat and $\mathrm{COP}_{\text {electricity }}$ using the following equations:

$$
\begin{gathered}
W_{E V A}=C p_{\text {fluid }} \cdot \rho_{\text {fluid }} \cdot F_{\text {fluid }} \cdot \Delta T_{E V A, \text { average }} \\
W_{\text {desorption }}=C p_{\text {fluid }} \cdot \rho_{\text {fluid }} \cdot F_{\text {fluid }} \cdot \Delta T_{\text {desorption,average }} \\
Q_{E v A \text { or desorption }}=\int_{0}^{t} W_{E V A \text { or desorption }} \mathrm{d} t \\
C O P_{\text {electricity }}=\frac{Q_{E V A}}{Q_{\text {electricity }}}
\end{gathered}
$$

\section{Experimental Results and Discussion}

\subsection{Adsorption Step}

Figure 5 shows the cooling heat output change over time at evaporator temperature of $15^{\circ} \mathrm{C}$ and $10^{\circ} \mathrm{C}$, respectively. Figure 6 shows the variation of adsorber pressure with time at $15^{\circ} \mathrm{C}$. The valve 1 and 3 were opened and MBP was switched on at $0 \mathrm{~s}$. In Figure 5, the cooling heat output without MBP is also indicated. The maximum cooling heat output obtained without MBP was $250 \mathrm{~W}$. On the other hand, the maximum cooling heat output with MBP at the input electrical power of $120 \mathrm{~W}$ was $380 \mathrm{~W}$. The obtained cooling heat output increased with increasing the input electrical power of MBP. The refrigerant vapor from the evaporator was compressed by MBP, and then was absorbed by FAM-Z05. The adsorber pressure increased quickly by using MBP, resulted a faster adsorption rate and a higher cooling heat output. However, when the input electrical power of MBP was $20 \mathrm{~W}$, the cooling heat output was lower than that of without MBP. In Figure 6, the adsorber pressure of $1.7 \mathrm{kPa}$ is the saturation pressure at $15^{\circ} \mathrm{C}$. The adsorber pressure was higher than the evaporator pressure when the MBP power was high. Time taken to reach the evaporator 

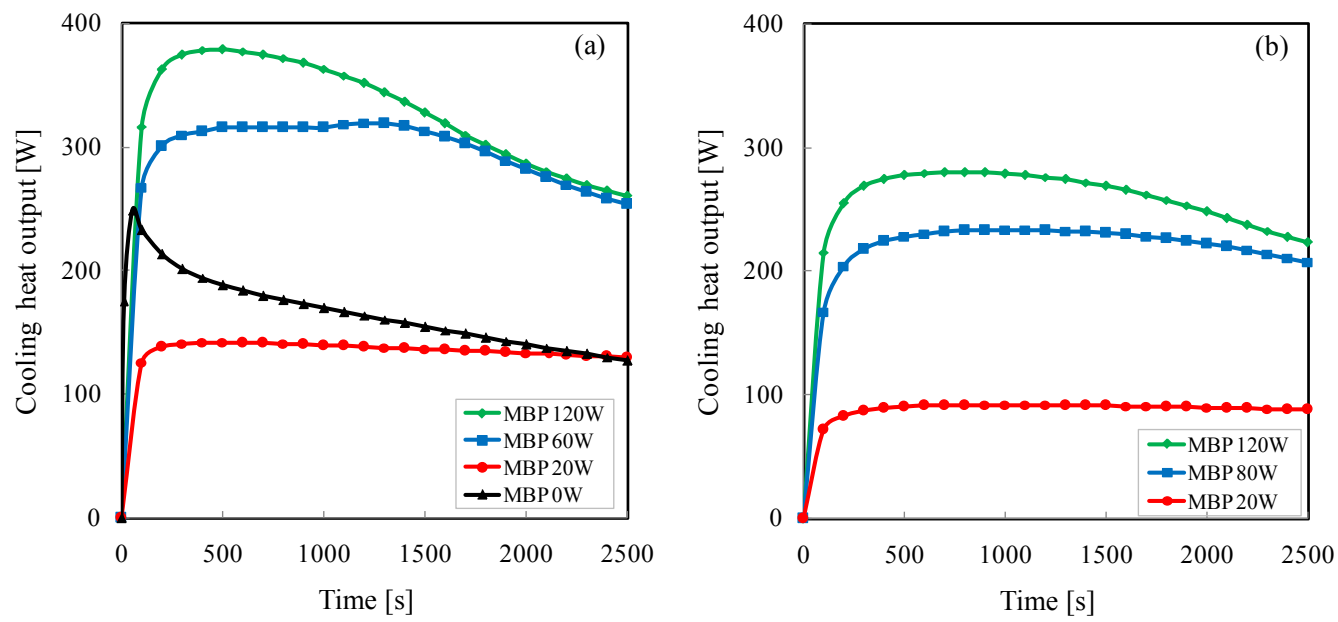

Figure 5. Time variation of cooling heat output for different MBP powers at $15^{\circ} \mathrm{C}(\mathrm{a})$ and $10^{\circ} \mathrm{C}(\mathrm{b})$.

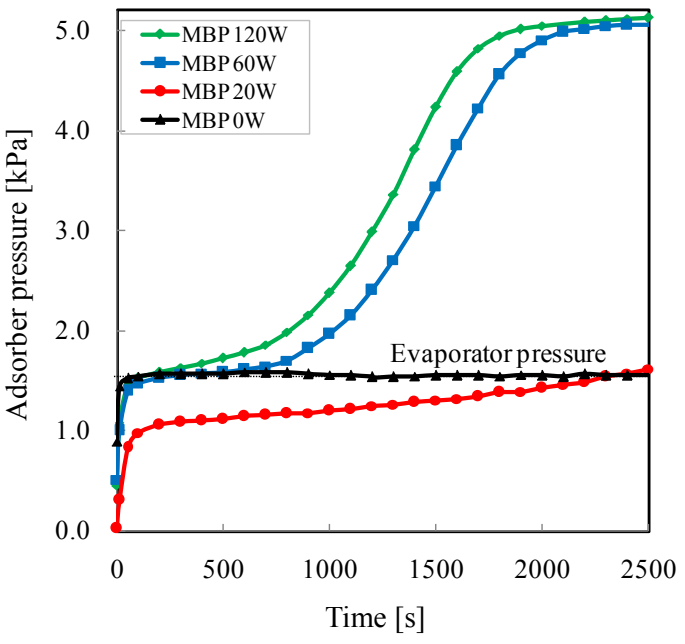

Figure 6. Effect of MBP power on the adsorber pressure in adsorption step.

pressure was $2300 \mathrm{~s}$ at $20 \mathrm{~W}$. The vapor transport between the evaporator and the adsorber was hampered by MBP, due to the rotational speed of MBP was extremely low at $20 \mathrm{~W}$. It resulted in a very slow vapor transport rate, which was slower than that of without MBP and the adsorption rate. Figure 7 shows the amount of cooling heat in the adsorption step. As can be seen from the results, the amount of cooling heat obtained with MBP was more than twice as much as that of without $\mathrm{MBP}$ at $15^{\circ} \mathrm{C}$. Furthermore, it was possible to obtain cooling heat at the evaporator temperature of $10^{\circ} \mathrm{C}$, which cannot be acquired without MBP. Therefore, the hybrid cycle with MBP can improve the cooling heat at low evaporator temperature was confirmed. Figure 8 shows the effect of input electrical power of $\mathrm{MBP}$ on $\mathrm{COP}_{\text {electricity }}$ which is the ratio of the cooling heat to the input electrical power of MBP. As can be seen from the results, the $\mathrm{COP}_{\text {electricity }}$ decreased with increasing the input electrical power of MBP. When the evaporator temperature was $15^{\circ} \mathrm{C}$, the $\mathrm{COP}_{\text {electricity }}$ for the input electrical power of 20,60 , and $120 \mathrm{~W}$ was 7.0, 5.0 and 3.0, respectively. In addition, the $\mathrm{COP}_{\text {electricity }}$ at the evaporator temperature of $10^{\circ} \mathrm{C}$ exhibited the same tendency as the results of 

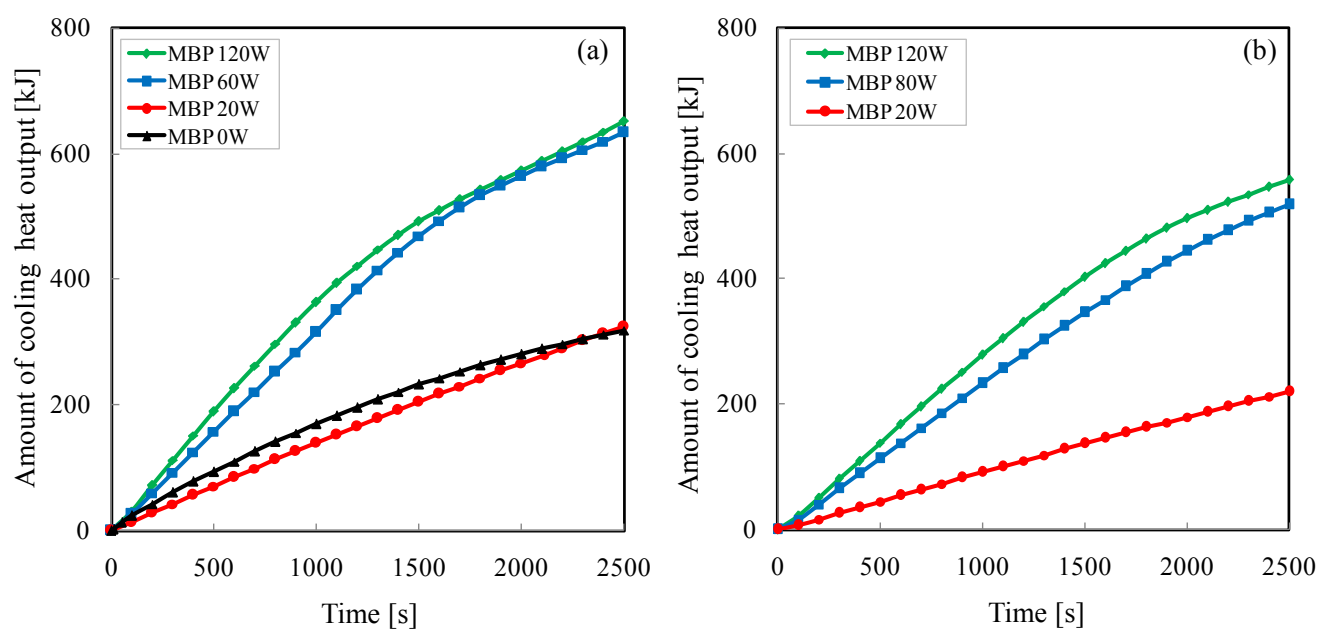

Figure 7. Time variation of cooling heat for different $\mathrm{MBP}$ powers at $15^{\circ} \mathrm{C}(\mathrm{a})$ and $10^{\circ} \mathrm{C}(\mathrm{b})$.
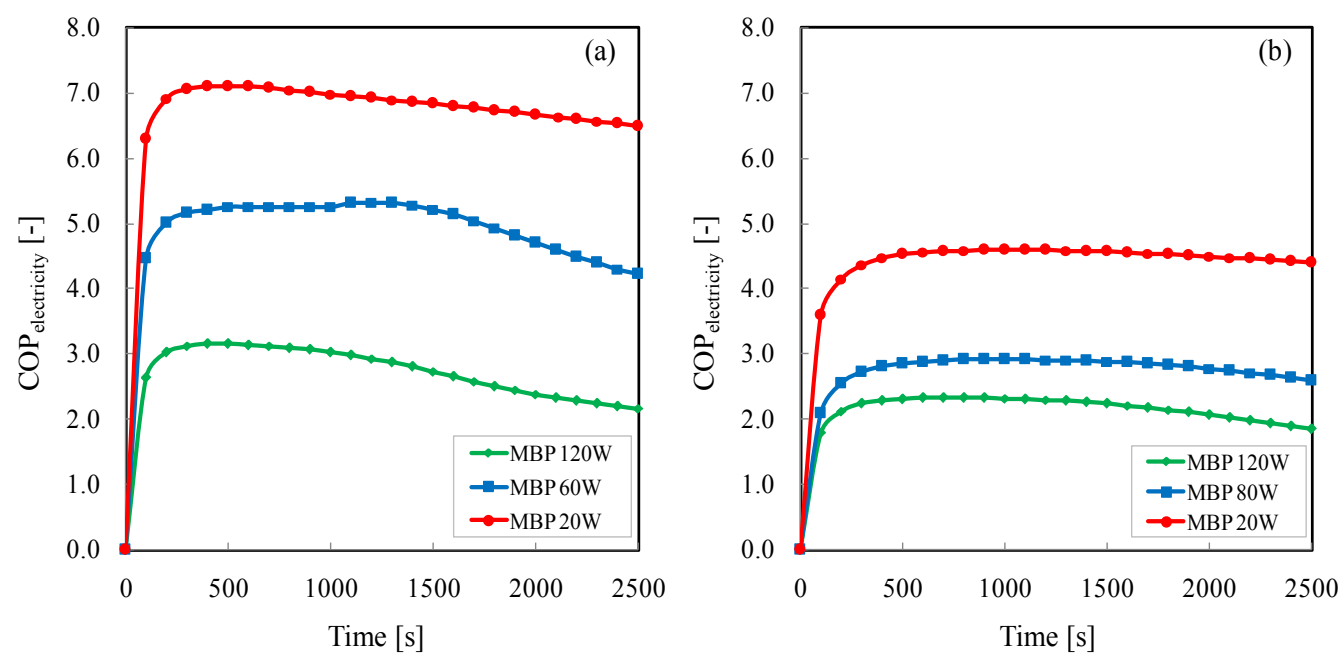

Figure 8. Effect of MBP power on the $\mathrm{COP}_{\text {electricity }}$ at the evaporator temperature of $15^{\circ} \mathrm{C}(\mathrm{a})$ and $10^{\circ} \mathrm{C}$ (b).

$15^{\circ} \mathrm{C}$. When the input electrical power of $\mathrm{MBP}$ was high, the $\mathrm{COP}_{\text {electricity }}$ of the hybrid cycle was less than or equal to that of mechanical chiller cycle. Due to the saturation pressure of water is lower than the conventional refrigerants, such as HFC and ammonia, which are commonly used in the mechanical chiller.

Figure 9 shows the effect of the input electrical power of MBP on the maximum cooling heat output and $\mathrm{COP}_{\text {electricity }}$ at the evaporator temperature of $15^{\circ} \mathrm{C}$. As shown in Figure 9, the cooling heat output increased as the input electrical power of MBP increased, whereas the $\mathrm{COP}_{\text {electricity }}$ displayed the opposite trend. The tradeoff between cooling heat output and $\mathrm{COP}_{\text {electricity }}$ was thus confirmed.

\subsection{Desorption Step}

We also studied the desorption step without and with MBP. The experimental apparatus was the same as that of the adsorption step. The desorption step was carried out after the adsorption step which had been conducted under the evaporator temperature of $15^{\circ} \mathrm{C}$ without MBP. Closed the valve 1 and 3, and then 
increased the adsorber temperature from the adsorption temperature to the desorption temperature. When the adsorber pressure became equal to or higher than the condenser pressure, valve 3 and 4 were opened so that the refrigerant vapor can transport into the condenser spontaneously. On the other hand, when the MBP was running and the valve 2 and 4 were opened instead of valve 3 and 4 , the refrigerant vapor was compressed into the condenser by MBP. The desorption temperature was set at $50^{\circ} \mathrm{C}$ and $60^{\circ} \mathrm{C}$ for the cycle without $\mathrm{MBP}, 55^{\circ} \mathrm{C}$, $50^{\circ} \mathrm{C}$ and $45^{\circ} \mathrm{C}$ for the cycle with MBP.

Figure 10 shows the variation of desorption heat input with time. $0 \mathrm{~s}$ of the horizontal axis corresponds to the timing of valve opening and MBP running. The results show that the desorption of refrigerant could proceed without MBP at $60^{\circ} \mathrm{C}$, reaching a maximum desorption heat input of approximately $600 \mathrm{~W}$. However, no desorption heat input can be obtained at $50^{\circ} \mathrm{C}$ without $\mathrm{MBP}$, due

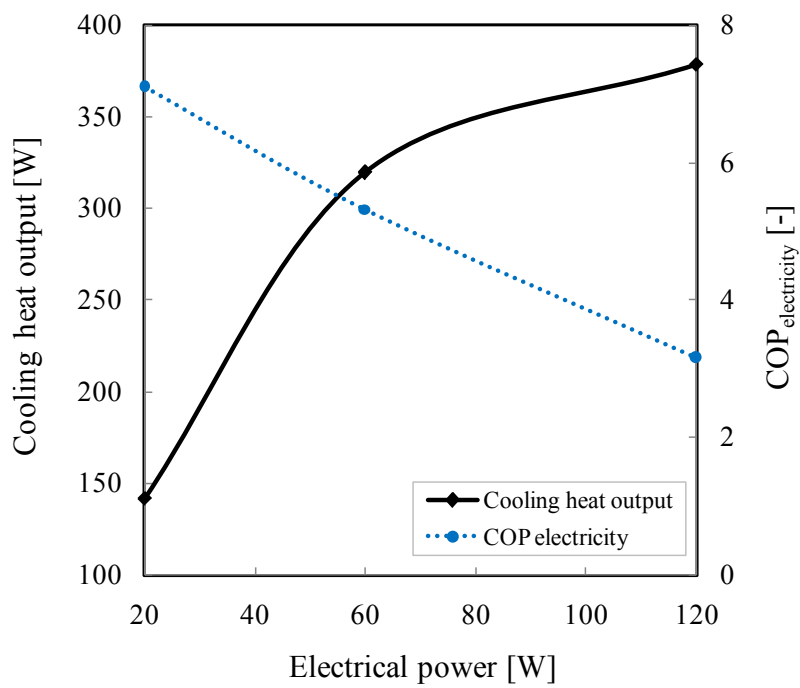

Figure 9. Effect of MBP power on the cooling heat output and the $\mathrm{COP}_{\text {electricity }}$ at $15^{\circ} \mathrm{C}$.

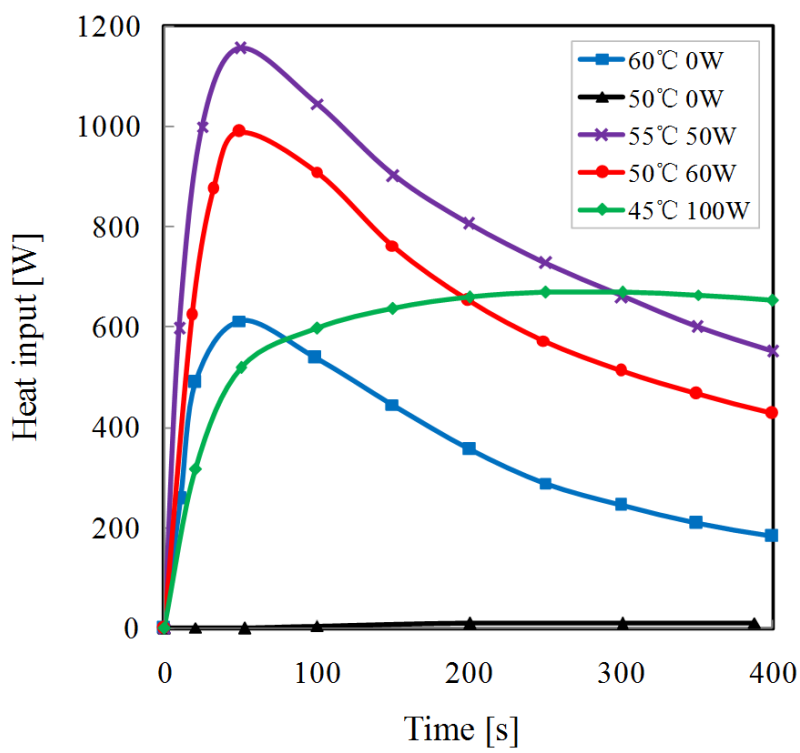

Figure 10. Time variation of desorption heat input for different MBP powers. 
to the poor adsorption capacity at this desorption temperature as can be seen from Figure 2. On the other hand, high desorption heat input was obtained with $\mathrm{MBP}$ at the desorption temperature of $50^{\circ} \mathrm{C}$ and $55^{\circ} \mathrm{C}$. When the input electrical power of MBP was $50 \mathrm{~W}$, the maximum desorption input power of about 1150 W was obtained at $50^{\circ} \mathrm{C}$, which was higher than that of at $60^{\circ} \mathrm{C}$ without MBP. The higher the input electrical power of MBP the lower the desorprion temperature can be used. Figure 11 shows the adsorber pressure change during desorption step. In the desorption step, the vapor transport rate is proportional to the pressure difference between the absorber and condenser. As can be seen from Figure 11, when valve 3 and 4 were opened, the adsorber pressure decreased to the condenser pressure immediately at $60^{\circ} \mathrm{C}$ without $\mathrm{MBP}$ and the desorption heat input was obtained. However, due to the adsorber pressure at $50^{\circ} \mathrm{C}$ was lower than the condenser pressure, when valve 3 and 4 were opened, the refrigerant vapor transported from condenser to adsorber, the opposite transport direction to $60^{\circ} \mathrm{C}$, resulted in the desorption of refrigerant could not proceed and no heat input was obtained. It would have been the same situation as at $50^{\circ} \mathrm{C}$ if MBP had not been used in the desorption step at $45^{\circ} \mathrm{C}$. When MBP was operating at $100 \mathrm{~W}$, the vapor from adsorber was compressed into condenser by MBP, and therefore the desorption heat input was acquired at $45^{\circ} \mathrm{C}$.

Figure 12 shows the amount of desorption heat. From Figure 12, it can be seen that the desorption heat could be obtained in less time by operating the MBP with an input electrical power of $100 \mathrm{~W}$, at the low desorption temperature of $45^{\circ} \mathrm{C}$. Thus, we confirmed that in comparison with the cycle without MBP, hybrid cycle could obtain cooling heat at lower desorption temperature.

\section{Conclusion}

We assembled a lab-scale FAM- $\mathrm{Z} 05 / \mathrm{H}_{2} \mathrm{O}$ type adsorption chiller cycle with and without MBP. The effect of the input electrical power of MBP on the perfor-

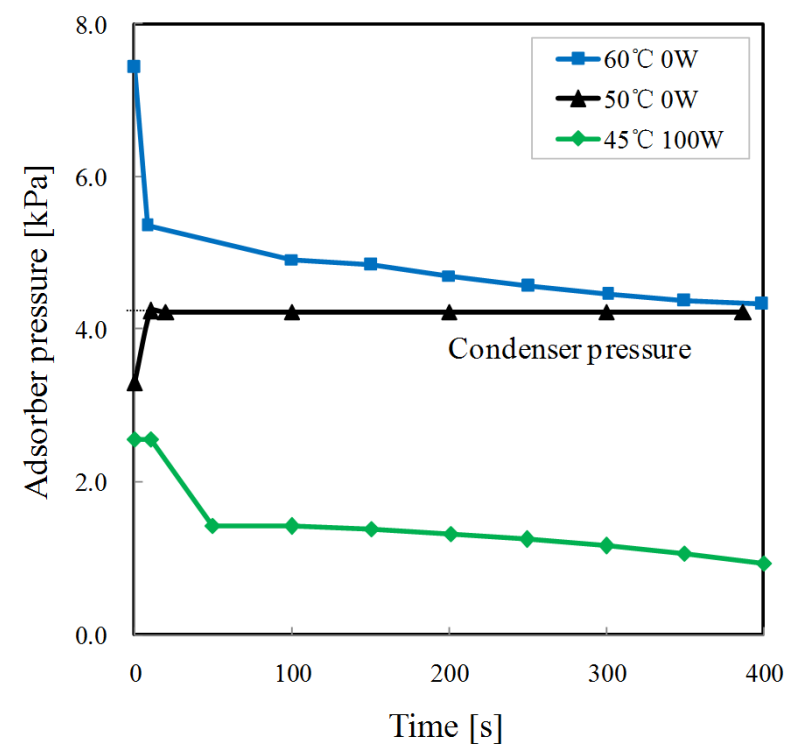

Figure 11. Effect of MBP power on the adsorber pressure in the desorption step. 


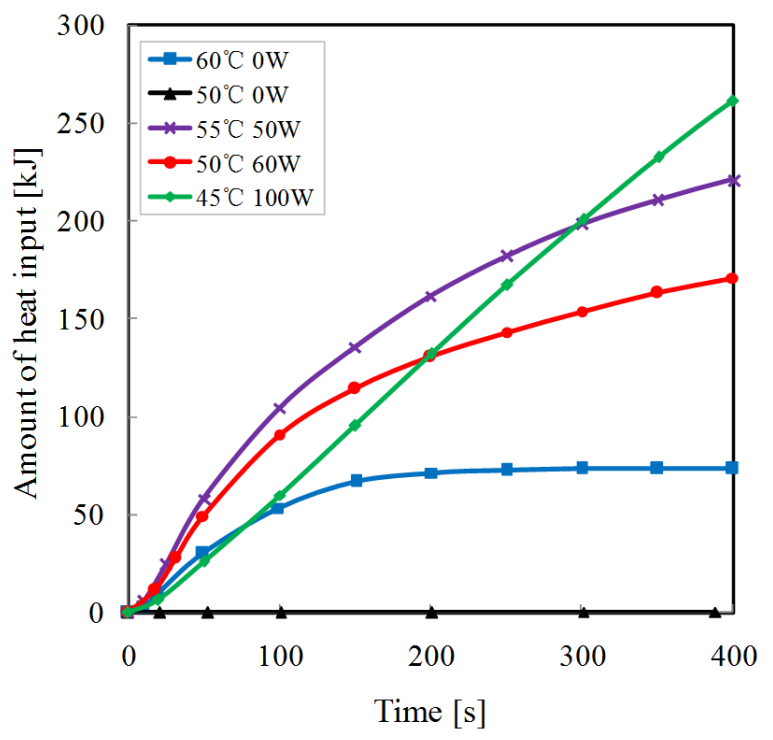

Figure 12. Time variation of amount of desorption heat for different MBP powers.

mances of adsorption step and desorption step were investigated separately. The following results were obtained.)

1) Adsorption step with MBP

The cooling heat output and the amount of cooling heat were improved and increased with the input electrical power of MBP. Moreover, the adsorption chiller could be operated at a lower evaporator temperature lever. On the other hand, COP electricity decreased with increasing the input electrical power of MBP and was less than or equal to mechanical chiller cycle at the high input electrical power.

2) Desorption step with MBP

The desorption heat input and the amount of heat input were improved and increased with the input electrical power of MBP. Desorption cycle could be effectively driven by a relatively low desorption temperature such as $45^{\circ} \mathrm{C}$, in comparison with the cycle without MBP.

The future work will be focused on the evaluation of cooling heat output and COP electricity when using MBP in the desorption step. A two-adsorber adsorption chiller will be constructed, which one adsorber is in adsorption cycle with MBP, the other one is in desorption cycle with MBP simultaneously. The performances of it will be investigated.

\section{References}

[1] Wu, W., Wang, B., Shi, W. and Li, X. (2014) Absorption Heating Technologies: A Review and Perspective. Applied Energy, 130, 51-71. https://doi.org/10.1016/j.apenergy.2014.05.027

[2] Demir, H., Mobedi, M. and Ülku, S. (2008) A Review on Adsorption Heat Pump: Problems and Solutions. Renewable and Sustainable Energy Review, 12, 2381-2403. https://doi.org/10.1016/j.rser.2007.06.005

[3] Lahmidi, H., Mauran, S. and Goetz, V. (2006) Definition, Test and Simulation of Thermochemical Storage Process Adapted to Solar Thermal Systems. Sol. Energy, 
80, 883-893. https://doi.org/10.1016/j.solener.2005.01.014

[4] Palomba, V., Vasta, S., Giacoppo, G., Calabrese, L., Gulli, G., La Rosa, D. and Freni, A. (2015) Design of an Innovative Graphite Exchanger for Adsorption Heat Pumps and Chillers. Energy Procedia, 81, 1030-1040.

https://doi.org/10.1016/j.egypro.2015.12.112

[5] Hirota, Y., Kobayashi, N., Watanabe, F., Hasatani, M., Uda, S. and Inaoka, H. (2008) Development of the Adsorber in the Ammonia and AC Combination Adsorption Heat Pump. Journal of Japan Society of Energy and Resources, 29, 35-41. http://www.jser.gr.jp/journal/journal_pdf/2008/journal200805_6.pdf

[6] Kakiuchi, H., Shimooka, S., Iwade, M., Oshima, K., Yamazaki, M., Terada, S., Watanabe, H. and Takewaki, T. (2005) Novel Water Vapor Adsorbent FAM-Z01 and Its Applicability to an Adsorption Heat Pump. Kagaku Kogaku Ronbunshu (Japan), 31, 361-364. https://doi.org/10.1252/kakoronbunshu.31.361

Submit or recommend next manuscript to SCIRP and we will provide best service for you:

Accepting pre-submission inquiries through Email, Facebook, LinkedIn, Twitter, etc. A wide selection of journals (inclusive of 9 subjects, more than 200 journals)

Providing 24-hour high-quality service

User-friendly online submission system

Fair and swift peer-review system

Efficient typesetting and proofreading procedure

Display of the result of downloads and visits, as well as the number of cited articles

Maximum dissemination of your research work

Submit your manuscript at: http://papersubmission.scirp.org/

Or contact msce@scirp.org 